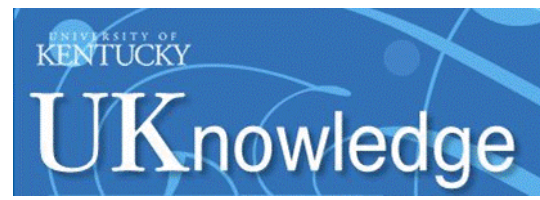

University of Kentucky

UKnowledge

Biosystems and Agricultural Engineering Faculty Publications

2-29-2016

\title{
Application of Recycled Media and Algae-Based Anaerobic Digestate in Scenedesmus Cultivation
}

\author{
Xinyi E \\ University of Kentucky, xinyi.e@uky.edu \\ Czarena Crofcheck \\ University of Kentucky, crofcheck@uky.edu \\ Mark Crocker \\ University of Kentucky, Mark.crocker@uky.edu
}

Follow this and additional works at: https://uknowledge.uky.edu/bae_facpub

Part of the Bioresource and Agricultural Engineering Commons, Oil, Gas, and Energy Commons, and the Sustainability Commons

Right click to open a feedback form in a new tab to let us know how this document benefits you.

\section{Repository Citation}

E, Xinyi; Crofcheck, Czarena; and Crocker, Mark, "Application of Recycled Media and Algae-Based Anaerobic Digestate in Scenedesmus Cultivation" (2016). Biosystems and Agricultural Engineering Faculty Publications. 17. https://uknowledge.uky.edu/bae_facpub/17

This Article is brought to you for free and open access by the Biosystems and Agricultural Engineering at UKnowledge. It has been accepted for inclusion in Biosystems and Agricultural Engineering Faculty Publications by an authorized administrator of UKnowledge. For more information, please contact UKnowledge@lsv.uky.edu. 


\section{Application of Recycled Media and Algae-Based Anaerobic Digestate in Scenedesmus Cultivation}

\section{Digital Object Identifier (DOI)}

https://doi.org/10.1063/1.4942782

\section{Notes/Citation Information}

Published in Journal of Renewable and Sustainable Energy, v. 8, issue 1, 013116, p. 1-14.

(c) Author(s) 2016.

All article content, except where otherwise noted, is licensed under a Creative Commons Attribution (CC BY) license (http://creativecommons.org/licenses/by/4.0/). 


\section{Application of recycled media and algae-based anaerobic digestate in Scenedesmus cultivation}

Xinyi E, Czarena Crofcheck, and Mark Crocker

Citation: Journal of Renewable and Sustainable Energy 8, 013116 (2016);

View online: https://doi.org/10.1063/1.4942782

View Table of Contents: http://aip.scitation.org/toc/rse/8/1

Published by the American Institute of Physics

\section{Articles you may be interested in}

Characterization of wind velocities in the upstream induction zone of a wind turbine using scanning continuouswave lidars

Journal of Renewable and Sustainable Energy 8, 013301 (2016); 10.1063/1.4940025

Influence analysis of blade chord length on the performance of a four-bladed Wollongong wind turbine Journal of Renewable and Sustainable Energy 8, 023303 (2016); 10.1063/1.4943093

A model for hot mirror coating on solar parabolic trough receivers

Journal of Renewable and Sustainable Energy 8, 053703 (2016); 10.1063/1.4965252

Ethanol production potential from conservation buffers in the inland Pacific Northwest Journal of Renewable and Sustainable Energy 8, 053102 (2016); 10.1063/1.4962414

Publisher's Note: "Synthetic generation of wind power time series for wind/storage systems integration studies" [J. Renewable Sustainable Energy 8, 013105 (2016)]

Journal of Renewable and Sustainable Energy 8, 019901 (2016); 10.1063/1.4940765

Price modeling of imported natural gas in Turkey

Journal of Renewable and Sustainable Energy 8, 013111 (2016); 10.1063/1.4942408 


\title{
Application of recycled media and algae-based anaerobic digestate in Scenedesmus cultivation
}

\author{
Xinyi E, ${ }^{1}$ Czarena Crofcheck, ${ }^{1, a)}$ and Mark Crocker ${ }^{2}$ \\ ${ }^{1}$ Department of Biosystems and Agricultural Engineering, University of Kentucky, \\ Lexington, Kentucky 40546, USA \\ ${ }^{2}$ Center for Applied Energy Research, University of Kentucky, Lexington, Kentucky 40511, \\ USA
}

(Received 29 May 2015; accepted 12 February 2016; published online 29 February 2016)

\begin{abstract}
To make large-algae cultivation systems sustainable, commercial fertilizer inputs should be minimized. One means of achieving this is to maximize the recycle of nutrients used in algae cultivation. In addition to recycling nutrient-containing water from algae harvesting and dewatering, after harvesting algal biomass can be used as a substrate for anaerobic digestion, which can then generate mineralized nutrients to be used for further cultivation. In this study, the effect of recycling media and using mineralized nutrients during Scenedesmus cultivation was investigated. The recycled media proved to be able to support cell growth with nutrient replenishment, and it could be recycled for cultivation up to four times. Algae biomass was subjected to anaerobic digestion, and the liquid digestate and the total digestate were tested as nutrient sources. The digestate was rich in ammonium ions and proved to be a sufficient replacement for urea. When both urea and ammonium ions were available in the media, the assimilation of urea by algal cells slowed down compared to the case where urea was the only nitrogen source. (C) 2016 Author(s). All article content, except where otherwise noted, is licensed under a Creative Commons Attribution (CC BY) license (http://creativecommons.org/ licenses/by/4.0/). [http://dx.doi.org/10.1063/1.4942782]
\end{abstract}

\section{INTRODUCTION}

Nutrient supplementation is critical for algae cultivation. Commercial fertilizers (such as urea, triple superphosphate, potash, and Sprint 330) or lab grade chemicals can provide the nutrients required for algae growth; however, as the cultivation scale expanding, the amount of nutrient required becomes significant and bulk fertilizers become more practicable. When the cultivation is performed in a continuous mode, algae cells have to be harvested intermittently, which generates algae biomass and media-containing residual nutrients. Algal biomass contains proteins, carbohydrates, lipids, nucleic acids, and inorganic compounds, which are potential nutrients for further algae cultivation. To alleviate the dependence on commercial fertilizers, recycled media and algae biomass residues (e.g., after processing of the biomass to obtain useful products) should be considered as secondary nutrient sources for the cultivation system.

The four most abundant elements in microalgae are carbon, oxygen, hydrogen, and nitrogen, where oxygen and hydrogen originate from water molecules, and carbon is assimilated from $\mathrm{CO}_{2}$. Nitrogen must be supplied through fertilizers such as urea, ammonium salts, and nitrate salts. Only the most reduced form of nitrogen $\left(\mathrm{NH}_{4}{ }^{+}\right)$can directly join the assimilation pathways and become the building block of proteins and nucleotides (Glass et al., 2009 and Syrett, 1988). Therefore, urea and nitrate have to be converted to $\mathrm{NH}_{4}{ }^{+}$by algae cells prior to assimilation

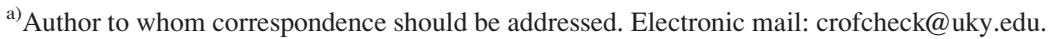




$$
\begin{gathered}
\mathrm{NO}_{3}^{-}+2 \mathrm{e}^{-}+2 \mathrm{H}^{+} \stackrel{\text { nitrate reductase }}{\longrightarrow} \mathrm{NO}_{2}^{-}+\mathrm{H}_{2} \mathrm{O} \\
\mathrm{NO}_{2}^{-}+6 \mathrm{e}^{-}+8 \mathrm{H}^{+} \stackrel{\text { nitrite reductase }}{\longrightarrow} \mathrm{NH}_{4}^{+}+2 \mathrm{H}_{2} \mathrm{O} \\
\mathrm{CO}\left(\mathrm{NH}_{2}\right)_{2}+\mathrm{HCO}_{3}^{-}+3 \mathrm{H}^{+}+\mathrm{ATP} \stackrel{\text { urea amidohydrolase }}{\longrightarrow} 2 \mathrm{NH}_{4}^{+}+2 \mathrm{CO}_{2}+\mathrm{ADP}+\mathrm{P}_{\mathrm{i}}
\end{gathered}
$$

Urea is transported into the cells via either passive or active transport (Syrett, 1988). Inside the cell, urea can be decomposed by urease and converted to ammonia and carbon dioxide. However, Chlorella and Chlamydomonas have been found to lack urease (Syrett, 1988 and Healey, 1973). These algae use urea amidohydrolase coupling with one molecule of ATP to break down one urea molecule (Syrett, 1988). Another theory posits that there are two enzymes involved in the hydrolysis: urea carboxylase coupled with ATP converts urea into allophanate, which is later hydrolyzed into ammonium and bicarbonate by allophanate hydrolase (Thompson and Muenster, 1971). On the other hand, $\mathrm{NH}_{4}{ }^{+}$directly enters the glutamine synthetaseglutamate synthase (GS-GltS) pathway, and then constitutes protein, chlorophyll, nucleotide, and phospholipid (Glass et al., 2009).

Another important element for algae cultivation is phosphorus, the building block of nucleic acids and ATP. Phosphorus is added as phosphate, which also functions as buffer to maintain a neutral $\mathrm{pH}$. When phosphorus is not limited in the environment, algae cells utilize it for synthesizing macromolecules (nucleic acids) and for energy storage (ATP). When external phosphorus becomes scarce, the polyphosphate is degraded to provide the phosphate for metabolic assimilation (Healey, 1973).

To make the cultivation system as sustainable as possible, the input of commercial fertilizers should be minimized. If the algae biomass is being utilized in anaerobic digestion (AD) for the production of biogas, then recycle of the mineralized nutrients in the AD digestate can be considered. Organic macromolecules are mineralized through anaerobic decomposition (Figure 1) (Moller and Muller, 2012). Anaerobic consortia break down hydrocarbons (carbohydrates and fatty acids) and generate biogas (a mixture of $\mathrm{CH}_{4}$ and $\mathrm{CO}_{2}$ ) (Figure 1) (Moller and Muller, 2012). Organic nitrogen is mineralized to $\mathrm{NH}_{3}$ (vented as biogas), or dissolved $\mathrm{NH}_{4}{ }^{+}$. Phosphate is released from macromolecules in the algae and is available for assimilation by anaerobic bacteria. Sulfur from cysteine or methionine is mineralized to $\mathrm{H}_{2} \mathrm{~S}$.

Using digestates as fertilizer is not a new concept. Farm manures are common substrates for anaerobic digesters, so digested manure slurry or co-digested crop residue and manure slurry are the most studied. Digestate is known as being rich in mineralized nutrients ( $\mathrm{N}$ and $\mathrm{P}$ ),

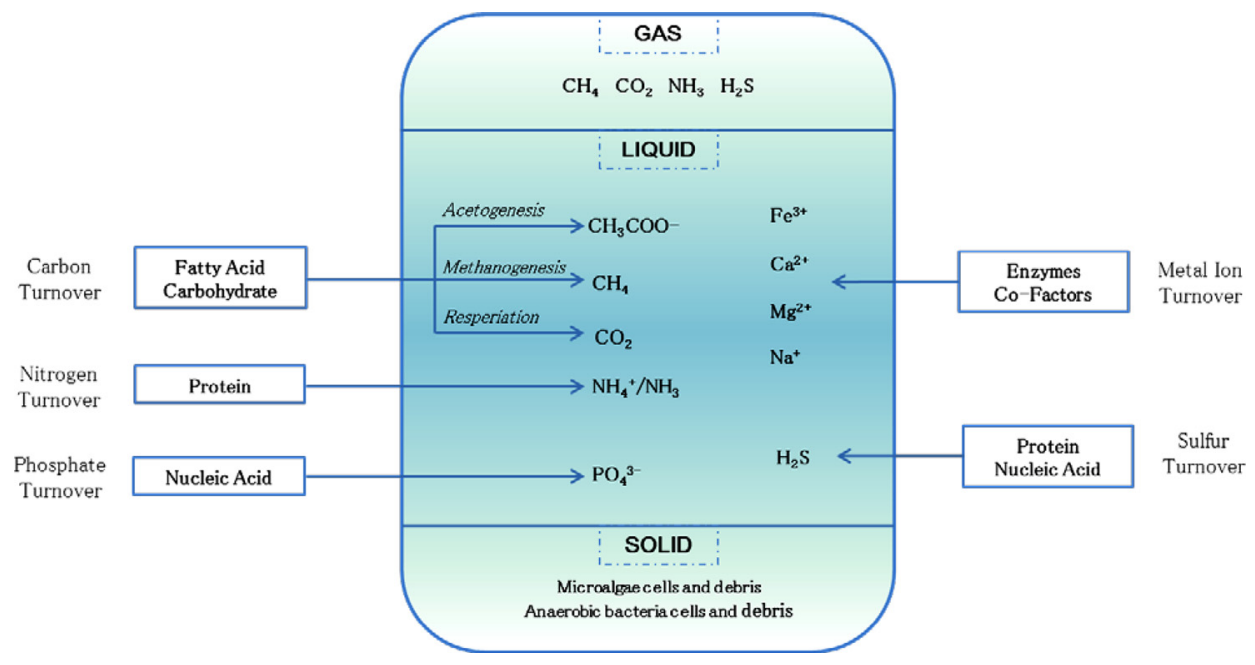

FIG. 1. Mineralization of macromolecules by anaerobic digestion (Moller and Muller, 2012). 
which also play a vital role in determining the suitability of a digestate as a fertilizer (Alburquerque et al., 2012).

Studies have shown that anaerobic digestates can potentially benefit crop growth as well as nitrogen uptake, although careful monitoring is necessary to ensure a constant soil quality in the early stages (Arthurson, 2009). In this study, a nutrient recycling strategy was tested for the cultivation of Scenedesmus acutus, which has been selected as a candidate for large scale $\mathrm{CO}_{2}$ mitigation and as a feedstock for anaerobic digestion and biodiesel production due to its high growth rate, hardiness, and oil content (E and Crofcheck, 2014; Shin et al., 2014; and Wilson et al., 2014). Used media generated through harvesting and dewatering of biomass was recycled back to the algae cultivation system four times. Separately, anaerobic digestate was considered as a nutrient source to replace commercial fertilizers. The effects of nutrient recycling and the use of digestate as a nutrient source on algae growth rate and nitrogen consumption were investigated.

\section{MATERIALS AND METHODS}

\section{Algae dry weight (DW) and growth rate}

Scenedesmus sp. biomass samples in suspension were filtered using Whatman binder-free glass microfiber filters (type 934-AH, $24 \mathrm{~mm}$ diameter). The DW of samples was measured after drying at $105^{\circ} \mathrm{C}$ for $24 \mathrm{~h}$. Biomass content was calculated as microalgal dry weight produced per liter $(\mathrm{g} / \mathrm{l})$. The slope of the growth curve in the exponential phase was used as the growth rate $(g / l / d)$. For algae cultivated in media with total digestate, a blank was taken before inoculation, and the algae dry weight was calculated as the difference between the sample dry weight and the dry weight of the blank.

\section{Media recycling}

Scenedesmus sp. was cultivated in urea media consisting of $\mathrm{CO}\left(\mathrm{NH}_{2}\right)_{2}(0.137 \mathrm{~g} / \mathrm{l}), \mathrm{KH}_{2} \mathrm{PO}_{4}$ $(0.118 \mathrm{~g} / \mathrm{l}), \mathrm{MgSO}_{4} .7 \mathrm{H}_{2} \mathrm{O}(0.109 \mathrm{~g} / \mathrm{l}), \mathrm{CaCl}_{2} \cdot 2 \mathrm{H}_{2} \mathrm{O}(0.055 \mathrm{~g} / \mathrm{l})$, and Na.EDTA.Fe $(0.02 \mathrm{~g} / \mathrm{l})$, prepared with autoclaved city water (Crofcheck et al., 2012). All tests were conducted in $500 \mathrm{ml}$ flasks, and each treatment had three replicates. The inoculation level was $0.05-0.10 \mathrm{~g} \mathrm{DW} / \mathrm{l}$. All test flasks were placed on a shaking table with $140 \mathrm{rpm}$ rotation. Filtered ambient air mixed with $3 \% \mathrm{CO}_{2}$ was bubbled into each flask at a flow rate of $0.15 \mathrm{l} / \mathrm{min}$. Warm and cool white fluorescent lights $\left(40 \mathrm{~W}, 60.5 \mu \mathrm{mol} / \mathrm{m}^{2}\right.$ per second) provided light for a $16 \mathrm{~h}: 8 \mathrm{~h}$ light:dark illumination period. The chamber temperature was controlled at $25^{\circ} \mathrm{C}$. Every $24 \mathrm{~h}, 8 \mathrm{ml}$ liquid samples were withdrawn to determine the algae dry weight.

Due to the limited cultivation volume ( $400 \mathrm{ml}$ per flask), stocks were prepared in advance. The stock flasks were kept under exactly same conditions as described above, and replenished with fresh nutrients (50\% of the original formula) weekly. Prior to being used as recycled media, stocks were centrifuged (3000 rpm for $20 \mathrm{~min}$ ) to remove algae cells. Supernatants were collected and replenished for the next generation of algae. In the first trial, no nutrient replenishment was applied before being used to cultivate the next generation of algae for 7 days. In the second trial, $50 \%$ of the original formula was mixed into the recycled medium prior to use (Figure 2).

The urea concentration in the medium was analyzed by Dionex ${ }^{\circledR}$ HPLC. Samples were centrifuged to remove algal cells, and filtered with a $0.45 \mu \mathrm{m}$ membrane syringe filter (Corning ${ }^{\circledR}$ ) before being injected into a HILIC-1 column $\left(\right.$ Acclaim $^{\circledR}$ Mixed-Mode, $4.6 \times 150 \mathrm{~mm}$ ) with a UV detector (Dionex ${ }^{\circledR}$ Ultimate 3000). The eluent was $30 / 70 \mathrm{v} / \mathrm{v} \mathrm{CH}_{3} \mathrm{CN} /$ de-ionized water, and the flow rate was $0.7 \mathrm{ml} / \mathrm{min}$. The operating temperature was $25^{\circ} \mathrm{C}$ and the injection volume was $50 \mu \mathrm{l}$.

\section{Digestate application}

Anaerobic digestate derived from raw algae was obtained from a CSTR reactor with a solids content of 7\%. The CSTR system used in this experiment consisted of a 51 glass tank, 


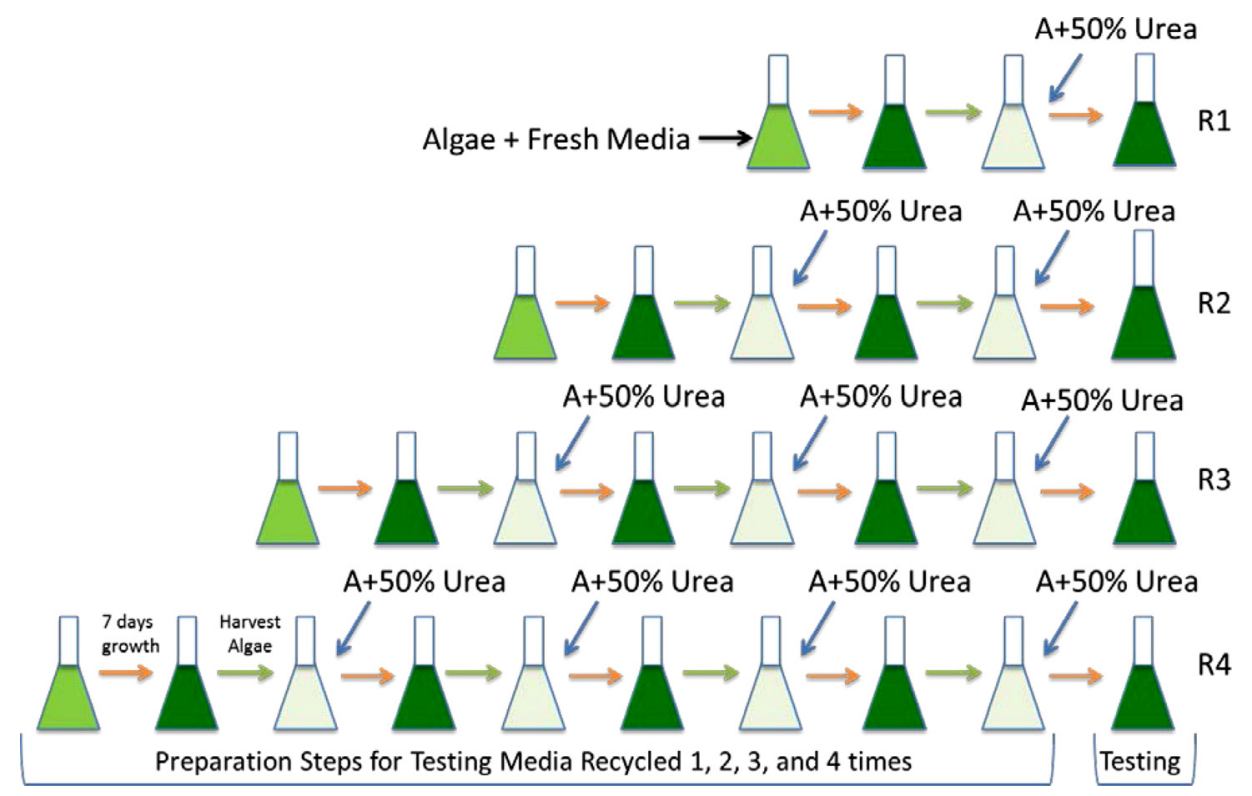

FIG. 2. Preparation steps for generating media that was recycled 1, 2, 3, and 4 times (referred to as R1, R2, R3, and R4, respectively), in which the nutrients added after each recycle were equivalent to $50 \%$ of the nutrients in the urea media. In the tests employing anaerobic digestate, the nutrient was either liquid or total digestate, in place of urea. Attempts were made to keep the amount of algae (A) added each time consistent.

feeding tube, stirring shaft and motor, heating mantel and temperature probe to keep the temperature at $37^{\circ} \mathrm{C}$, gas outlet three-way valve, condensate trap, and a Ritter Milli Gas Counter (Ritter, Germany). The reactor was fed with primary sludge until stabilized, and then switched to raw algae to acclimate for 3 months prior to the collection of digestate. The $\mathrm{pH}$ of the digestate during digestion was maintained between 7 and 7.5 by adding $6 \mathrm{~mol} / \mathrm{l} \mathrm{HCl}$ solution to prevent ammonia overloading.

The digestate was added to the media in two forms: liquid only (i.e., liquid anaerobic digestate, LAD) or total anaerobic digestate (the mixture of liquid and solid slurry) (TAD). Isolation of the $\mathrm{LAD}$ was performed by centrifuging the TAD at $3000 \mathrm{rpm}$ for $10 \mathrm{~min}$. Prior to algae inoculation, liquid (LAD) and slurry (TAD) were diluted to match the nutrient level in the urea medium. The conditions used for algae cultivation were as described above. Growth curves and $\mathrm{NH}_{4}{ }^{+}$consumption curves were recorded to evaluate the differences between algae growth obtained using the digestates and commercial nutrients.

\section{Nutrient analysis}

Soluble nutrients (nitrogen, phosphate, potassium, and magnesium) in the anaerobic digestate and recycled media were determined by ion chromatography (Dionex ${ }^{\circledR}$ ICS-1100). Filtered samples were sealed in Dione ${ }^{\circledR}$ Polyvials and loaded into a Dionex ${ }^{\circledR}$ ICS AS-DV autosampler. The eluent was $4.5 \mathrm{mM}$ sodium carbonate and $1.4 \mathrm{mM}$ sodium bicarbonate, and the flow rate was $1.0 \mathrm{ml} / \mathrm{min}$. Samples were injected into the cation column $(\mathrm{CS} 16)$ at $40^{\circ} \mathrm{C}$, the ions being detected by a conductivity detector. Inductively Coupled Plasma-Optical Emission Spectroscopy (ICP-OES) was used to quantify the elemental composition of algae and the solid digestate. The instrument used was a Varian Vista Pro ICP-OES under the following operating conditions: $1.2 \mathrm{~kW}$ power, $15 \mathrm{l} / \mathrm{min}$ plasma flow, $0.91 / \mathrm{min}$ nebulizer flow, $8 \mathrm{~s}$ replicate read time, and $1 \mathrm{ppm}$ yttrium internal standard. Algae cells or solid digestates were washed with deionized water, centrifuged to remove excess water, and oven-dried overnight. The solid samples were acid digested and diluted with deionized water before being injected into the nebulizer. 


\section{Statistical analysis}

Analysis of variance (ANOVA) and mean separation test (equivalent to Fisher's least significant difference test) were conducted by using PROC GLM and MEANS/LSD (SAS Institute, USA). All statistics were considered significant at $\mathrm{p}<0.05$.

\section{RESULTS AND DISCUSSIONS}

\section{Effects of recycled media on growth}

The results of experiments in which nutrient media were recycled without the addition of fresh nutrients are shown in Figure 3. Without nutrient replenishment, algae growth gradually ceased and the culture become yellowish in color as nutrient deficiency occurred. The specific growth rate of control (fresh) culture was $0.11 \mathrm{~g} / 1 / \mathrm{d}$ (Figure 4), which was significantly higher than the cultures from the recycled media $(0.03-0.04 \mathrm{~g} / \mathrm{l} / \mathrm{d}, \mathrm{F}=96.11, \mathrm{P}<0.0001)$. When Chaetomorpha linum encountered nitrogen depletion, both protein and chlorophyll contents declined within days (McGlathery and Pedersen, 1999 and Young and Beardall, 2003). Interestingly, during nitrogen starvation, both starch and sugar contents increased compared to nitrogen saturation condition (McGlathery and Pedersen, 1999). In this study, when nitrogen was limited, the growth of Scenedesmus was not completely zero (Figures 4 and 5), despite the obvious chlorosis. It seems when Scenedesmus had limited nitrogen supply, internal N was continuously diluted as cell division occurred (Young and Beardall, 2003). Photosynthesis slowed down due to the impaired chlorophyll synthesis pathway, but carbon assimilation still occurred when the specific growth rate was only $30 \%$ of the control. The other major nutrients (phosphate, potassium, and magnesium) were added in excess to ensure that growth would be nitrogen limited.

The growth rate of Scenedesmus was also studied in the nutrient-added recycled media, where the recycled media being replenished with $50 \%$ of the urea media nutrients after the first week of cultivation. The results of these experiments were summarized in Figure 6. The slopes of the growth curves in fresh or recycled media varied from week to week, although the patterns were similar. Given that both sets of media were freshly prepared; in the first week, the two curves almost overlapped, the specific growth rates being 0.12 and $0.11 \mathrm{~g} / \mathrm{l} / \mathrm{day}$. In the second week, the two curves overlapped until the end of day 7 , at which point the recycled media samples exhibited slightly less robust growth. In the third week, the fresh media samples encountered an environmental shock (the $\mathrm{CO}_{2}$ supply was interrupted for about $12 \mathrm{~h}$ ) inducing a prolonged lag phase. Even though the two sets of samples were cultured under exactly the same conditions, the recycled media samples appeared to be unaffected by the environmental

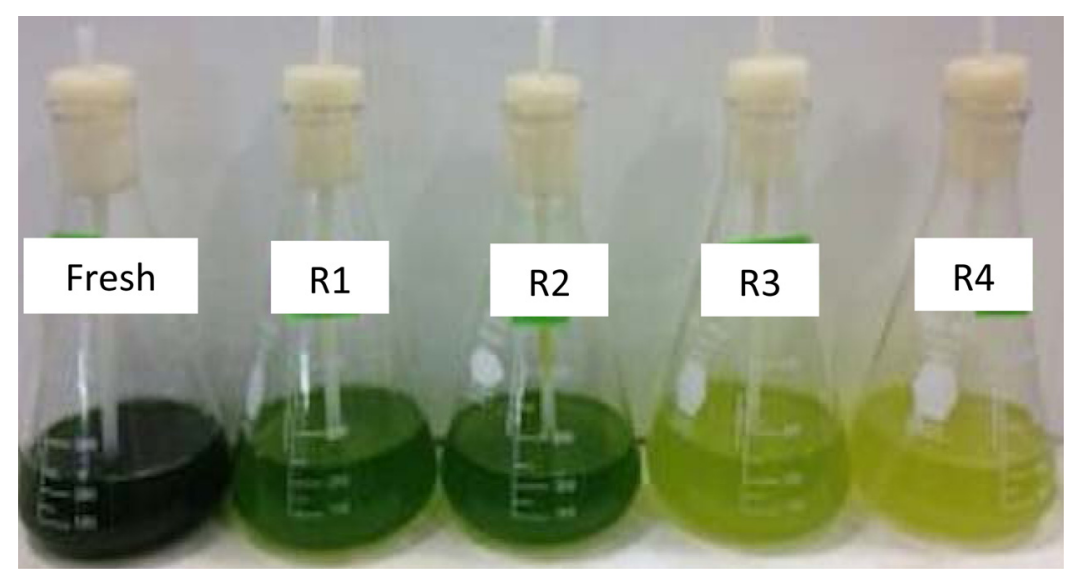

FIG. 3. Effect of nitrogen deprivation on algae color after 7 days of cultivation. Flasks from left to right contain fresh media, media recycled once $(\mathrm{R} 1)$, media recycled twice $(\mathrm{R} 2)$, media recycled three times (R3), and media recycled four times (R4). 


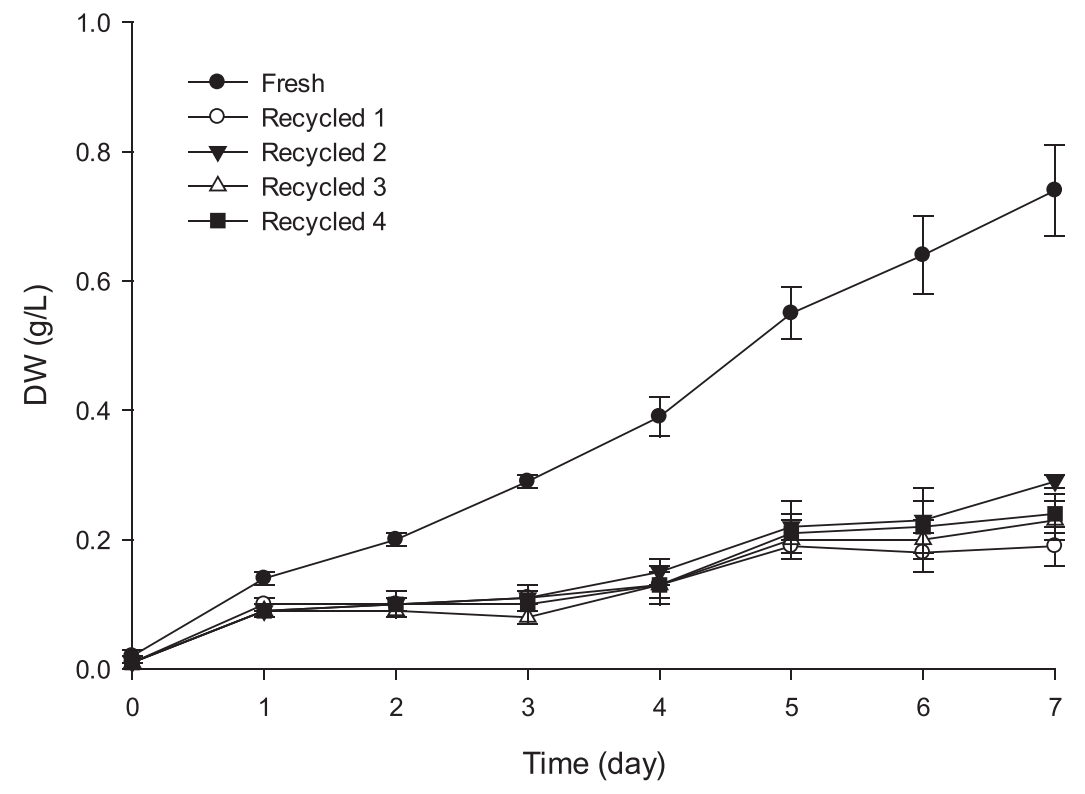

FIG. 4. Growth curves of Scenedesmus growing in fresh or recycled media without nutrient replenishment. Error bars represent standard errors $(n=3)$.

shock; in contrast, the fresh media samples exhibited a 4-day lag phase. They produced similar amount of biomass at the end of week $3(0.46 \mathrm{~g} / \mathrm{l}$ vs. $0.50 \mathrm{~g} / \mathrm{l}, \mathrm{F}=2.46, \mathrm{p}=0.58)$. After media had been recycled four times (the fifth week), it still showed great potential to support algae growth: no significant lag phase was observed, and the biomass accumulation was comparable to previous weeks, although the fresh media presented a higher specific growth rate from the second week to the fifth week.

However, considering that the recycled media were dosed with only $50 \%$ of the standard amount of urea (i.e., as used for the fresh media), the results are promising. Evidently, media can be reused with nutrient replenishment in dilute cultivation systems (biomass density of less

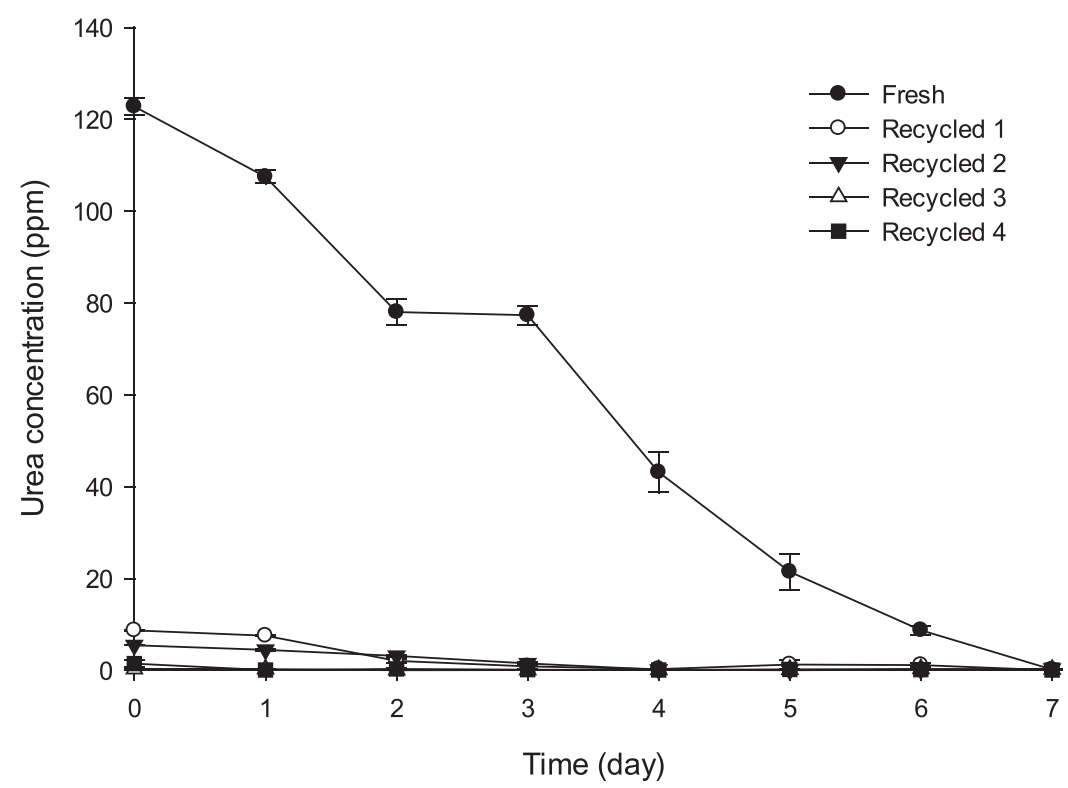

FIG. 5. Urea consumption of Scenedesmus growing in fresh or recycled media without nutrient replenishment. Error bars represent standard errors $(\mathrm{n}=3)$. 


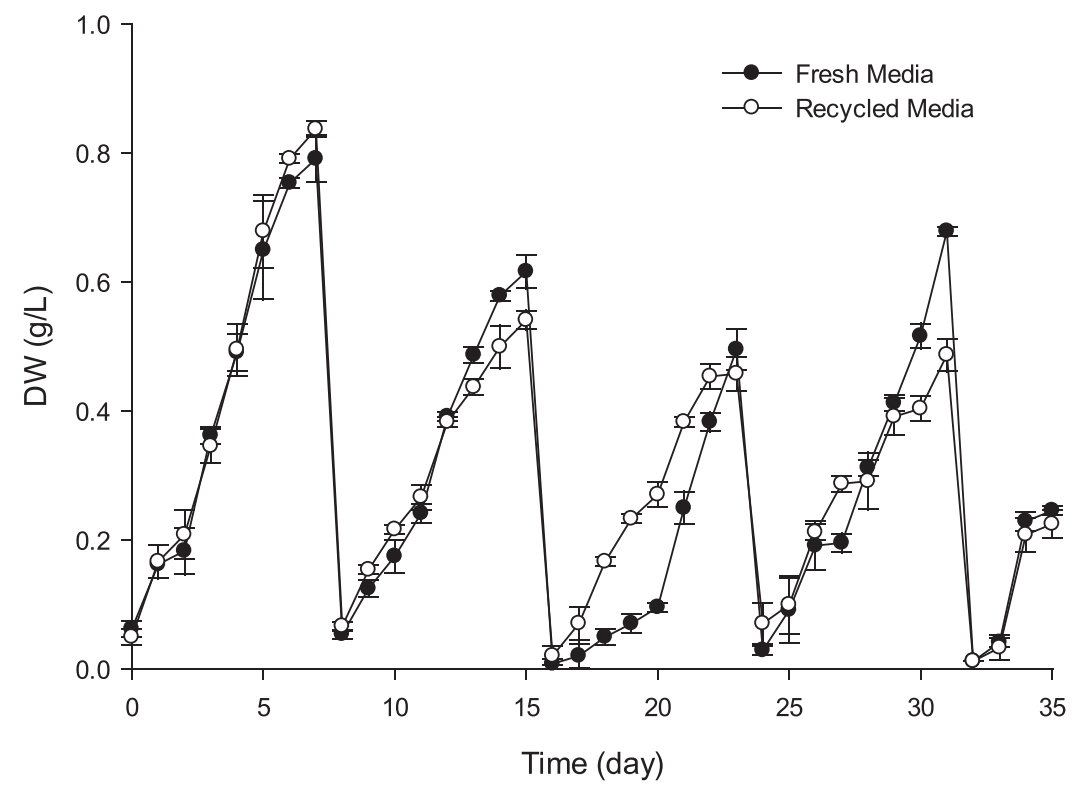

FIG. 6. Growth curves of Scenedesmus in fresh and recycled media, where the recycled media was replenished with $50 \%$ of the urea media nutrients after the first week. Error bars represent standard errors $(n=3)$. Numbers are accumulated algae yields $(\mathrm{g} / \mathrm{l})$.

than $1 \mathrm{~g} / \mathrm{l}$ ). In ultrahigh cell density cultures (UCDC), defined as cultures having more than $10 \mathrm{~g} / \mathrm{l}$ cell mass, frequent replacement of the growth media, as opposed to nutrient replenishment, is needed to ensure high productivity (Richmond, 2004). This follows from the fact that several microalgae have been identified to excrete certain growth inhibitors to control the total cell population, such as Chlorella vulgaris, Skeletonema costatum, Cladosiphon okamuranus, and Haematococcus pluvialis (Richmond, 2004). Growth inhibition was most prominent in UCDC, as compared to low density cell cultures; in such cases, inhibitors need to be frequently removed by replacing the media to ensure high productivity (Richmond, 2004).

\section{Composition of anaerobic digestate}

Table I showed the composition of the Scenedesmus sp. algae used in this work, while the nutrient profiles of the resulting soluble and insoluble anaerobic digestate fractions were shown

TABLE I. Elemental composition of Scenedesmus used in this study (by weight).

\begin{tabular}{lc}
\hline \hline Element & $\%$ \\
\hline Carbon (C) & 50.02 \\
Oxygen (O) & 25.98 \\
Hydrogen (H) & 7.43 \\
Nitrogen (N) & 7.80 \\
Phosphorus (P) & 2.20 \\
Potassium (K) & 0.82 \\
Magnesium (Mg) & 0.39 \\
Sulfur (S) & 0.69 \\
Iron (Fe) & 0.43 \\
Calcium (Ca) & 1.3 \\
Manganese (Mn) & 0.0023 \\
Copper (Cu) & 0.0021 \\
Zinc (Zn) & 0.0053 \\
\hline \hline
\end{tabular}


TABLE II. Nutrient profile of soluble and solid anaerobic digestate $(n=3)$.

\begin{tabular}{lcc}
\hline \hline & Nutrient & Concentration \\
\hline Soluble fraction $(\mathrm{ppm})$ & $\mathrm{NO}_{3}{ }^{-}$ & $72 \pm 3$ \\
& $\mathrm{NH}^{+}$ & $967 \pm 9$ \\
& $\mathrm{~K}^{+}$ & $238 \pm 6$ \\
Solid fraction $(\% \mathrm{w} / \mathrm{dw})$ & $\mathrm{PO}_{4}{ }^{3-}$ & $448 \pm 15$ \\
& $\mathrm{~N}$ & $8.68 \pm 0.21$ \\
& $\mathrm{P}$ & $2.13 \pm 0.06$ \\
& $\mathrm{~K}$ & $0.39 \pm 0.01$ \\
& $\mathrm{Mg}$ & $0.62 \pm 0.04$ \\
& $\mathrm{Fe}$ & $0.96 \pm 0.01$ \\
& $\mathrm{Ca}$ & $1.90 \pm 0.03$ \\
\hline \hline
\end{tabular}

in Table II. The digestate was rich in soluble nutrients and its solid fraction also contained significant amounts of $\mathrm{N}, \mathrm{P}$, and $\mathrm{K}$. Ammonium ions are an ideal replacement for urea, which together with the presence of soluble $\mathrm{K}^{+}$and $\mathrm{PO}_{4}{ }^{3-}$ renders the digestate a viable nutrient source. The composition of the solid fraction was similar to the composition of Scenedesmus, especially for $\mathrm{N}, \mathrm{P}$, and $\mathrm{Ca}$. The similarity between these two composition profiles which indicates the major component in the solid digestate was likely undigested algal cells.

\section{Use of anaerobic digestate as a nutrient source}

Anaerobic digestate was rich in mineralized nutrients and contained a substantial amount of insoluble particles, mainly algae cell debris. The insoluble particles contributed to high turbidity when added to cultivation media (Figure 7). In initial experiments, anaerobic digestate was tested in tap water as the sole nutrient source. The amount of digestate added was adjusted to be similar to the nutrient level in urea media (Tables II and III).

The addition of liquid digestate (LAD) or total digestate (TAD) showed a positive impact on algae growth (Figure 8). Algae in the dark, turbid media containing insoluble particles (TAD) did not appear to have a prolonged lag phase compared to the control or liquid digestate samples (LAD). For all the samples, exponential growth began after the first day. Over 9 days of cultivation, the control had the lowest specific growth rate of $0.086 \mathrm{~g} / \mathrm{l} / \mathrm{day}(\mathrm{F}=9.52$, $\mathrm{p}=0.0138)$ and lowest biomass accumulation of $0.86 \mathrm{~g} / \mathrm{l}(\mathrm{F}=9.75, \mathrm{p}=0.013)$. When mixing liquid digestate with tap water to constitute the growth media, the specific growth rate obtained

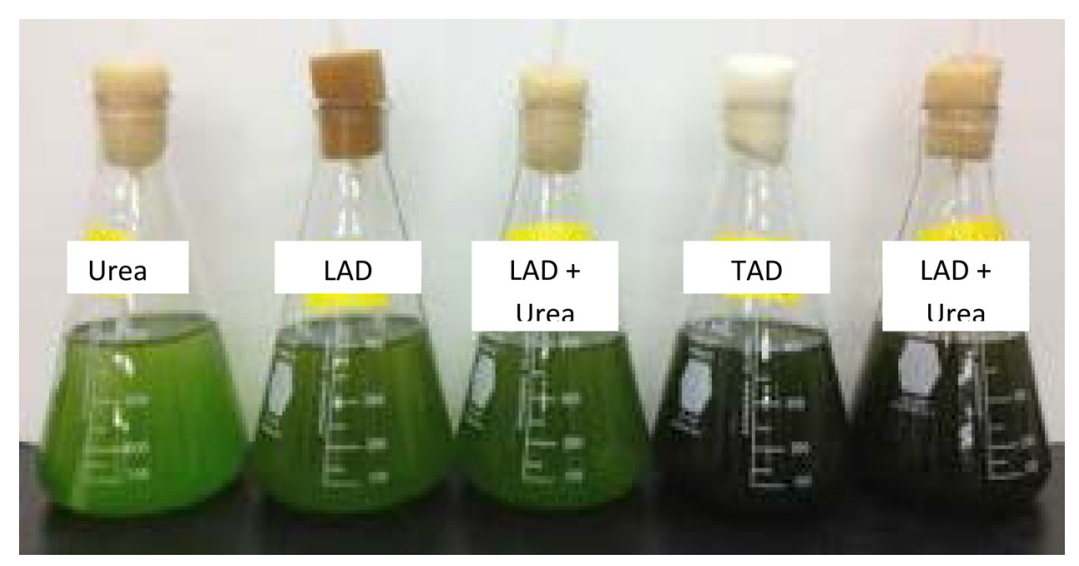

FIG. 7. Effect of liquid and solid digestate on culture color and turbidity. From left to right, flasks contain fresh urea media (Urea), tap water mixed with liquid digestate (LAD), fresh urea media mixed with liquid digestate (LAD + Urea), tap water mixed with total digestate (TAD), and fresh urea media mixed with total digestate (LAD + Urea). 
TABLE III. Elemental composition of urea media and media made with liquid digestate (LAD) and total digestate (TAD) ( \pm standard error, $\mathrm{n}=3$ ).

\begin{tabular}{lccc}
\hline \hline & Urea ppm & LAD ppm & TAD ppm \\
\hline $\mathrm{N}$ & $54.2 \pm 2.7$ & $76.6 \pm 2.5$ & $40.6 \pm 1.1$ \\
$\mathrm{P}$ & $24.7 \pm 0.3$ & $14.0 \pm 0.5$ & $9.4 \pm 0.3$ \\
$\mathrm{~K}$ & $31.6 \pm 0.1$ & $13.9 \pm 0.6$ & $4.3 \pm 0.1$ \\
$\mathrm{Mg}$ & $20.7 \pm 0.1$ & $6.3 \pm 0.3$ & $10.4 \pm 0.1$ \\
\hline \hline
\end{tabular}

was $0.095 \mathrm{~g} / \mathrm{l} / \mathrm{day}$ and the final biomass accumulation was $0.95 \mathrm{~g} / \mathrm{l}$. When mixing the total digestate, including both liquid and solid fractions, with tap water to constitute the growth media, the specific growth rate was $0.11 \mathrm{~g} / \mathrm{l} / \mathrm{day}$ and final biomass accumulation was $1.08 \mathrm{~g} / \mathrm{l}$.

Iyovo et al. (2010) applied the digestate from the anaerobic co-digestion of poultry manure, paper pulp, and C. vulgaris to the cultivation media for $C$. vulgaris. They tested a series of $\mathrm{C} / \mathrm{N}$ ratios for the co-digestion: $\mathrm{C} / \mathrm{N} 26,30,31,34$, and 37. After applying the AD digestate (dilution factor was 50) extracted from all $\mathrm{C} / \mathrm{N}$ co-digestions, higher biomass accumulation rates were observed for all digestate compared to the standard growth media. The highest biomass accumulation at the end was $7.8 \mathrm{~g} / \mathrm{l}$ when the culture grew in the $\mathrm{AD}$ digestate from $\mathrm{C} / \mathrm{N} 30$ codigestion, and the biomass accumulation for the standard media was $5.88 \mathrm{~g} / \mathrm{l}$.

Franchino et al. (2013) reported that adding anaerobic digestate to the media suppressed the algae growth. The digestate they used was the effluent of a digester fed with wastewaters from cattle slurry and whey. The highest dilution factor was 25 , and the biomass accumulation from the algae cultivation with digestate media was only $50 \%$ of the value from the standard cultivation media. In this study, the total digestate was diluted by tap water at a ratio of 1:120, which resulted in a similar nitrogen concentration as for the standard urea media (Table III).

Alburquerque et al. (2012) investigated the phytotoxicity of anaerobically digested manure slurries in lettuce and cress hydroponics. Directly using the digestate without any dilution caused no germination or biomass accumulation, which was explained by the high salinity of the digestate. Diluting to $20 \%$ of concentration, seeds germinated, and $1 \%$ digestate concentration gave the best germination and highest biomass accumulation. Researchers linked the

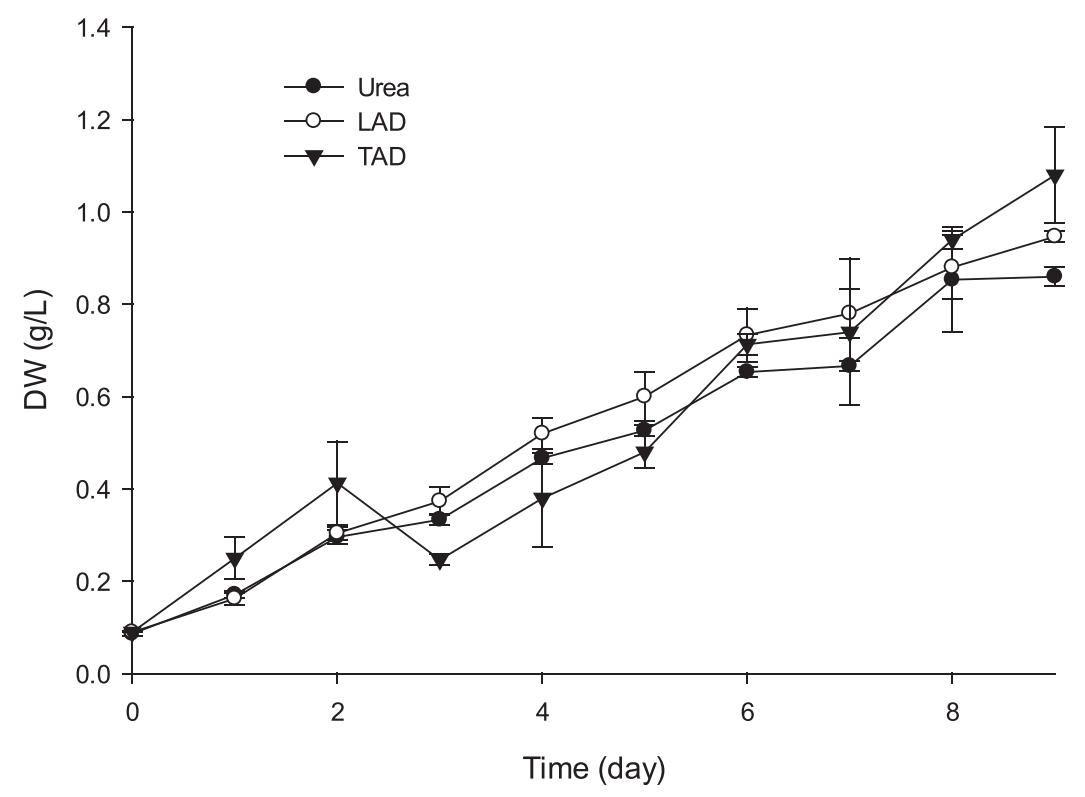

FIG. 8. Algae growth in media made with urea, liquid digestate (LAD), and total digestate (TAD). Error bars represent standard errors $(\mathrm{n}=3)$. 
fertilizing performance of various dilutions of digestate to organic matter content, and concluded that when dissolved organic carbon (DOC) and biochemical oxygen demand (BOD5) were less than 1.5 or $2.5 \mathrm{~g} / \mathrm{l}$, respectively, the digestate was suitable for lettuce and cress hydroponics. Therefore, it was indicated that proper dilution was important to ensure the digestate was a source of nutrients, while being non-toxic to the organism under cultivation.

As shown in Figure 9, nitrogen-one of the major building blocks for protein and chlorophyll production-was consumed steadily during algae growth in the form of urea $\mathrm{or}_{\mathrm{NH}_{4}}{ }^{+}$. For the control, in which urea was the only nitrogen source, there was a linear decrease in urea concentration over 7 days and only $15 \mathrm{ppm}$ of urea remained at the end of the experiment. For LAD media and TAD media, in which ammonium was the only nitrogen source, ammonium was quickly depleted, especially for TAD media for which ammonium was exhausted at day 5 . Owing to the fact that LAD media had more ammonium to start with compared to TAD media (98 vs. $52 \mathrm{ppm}$ ), its supply was not exhausted, $22 \mathrm{ppm}$ of ammonium remaining on day 7. Nevertheless, both samples had similar ammonium consumption rates (10.82 vs. $11.40 \mathrm{ppm} / \mathrm{d})$.

Experiments were also performed in which total digestate was added to the recycled media as a nutrient source. A prolonged lag phase was observed (Figure 10), exponential growth commencing after 3 days. The lag phase was likely due to the high initial turbidity as well as the low biomass concentration used for initial inoculation compared to samples fed with total digestate in the experiments above (Figure 8 vs. Figure 10, 0.09 vs. $0.02 \mathrm{~g} / \mathrm{l}$ ). The specific growth rates of the samples with total digestate had no significant difference $(0.116-0.0126 \mathrm{~g} / \mathrm{l} / \mathrm{d}$, $\mathrm{F}=0.93, \mathrm{p}=0.4867$ ); the media without any total digestate did not experience any growth delay, but showed lower specific growth rate $(0.104 \mathrm{~g} / \mathrm{l} / \mathrm{d}, \mathrm{F}=3.37, \mathrm{p}=0.0394)$. Indeed, other than the pronounced lag phase, the use of recycled media and TAD did not result in any deleterious effects on algae growth compared to the control.

For the control without addition of total digestate, the urea $(123 \mathrm{ppm})$ was exhausted when the biomass concentration reached $0.75 \mathrm{~g} / \mathrm{l}$. However, with the addition of digestate containing ammonium, there was still urea remaining at the end of the experiment. The initial urea concentration in the fresh media with TAD was close to $136 \mathrm{ppm}$, and after 9 days of cultivation, $25 \mathrm{ppm}$ urea was left in the system at the biomass concentration of $0.91 \mathrm{~g} / 1$ (Figure 11). The initial ammonium dosage ranged from 13 to $18 \mathrm{ppm}$ in all flasks. In the flasks with fresh media and $\mathrm{TAD}$, there was an increase of ammonium as the urea concentration decreased in the first

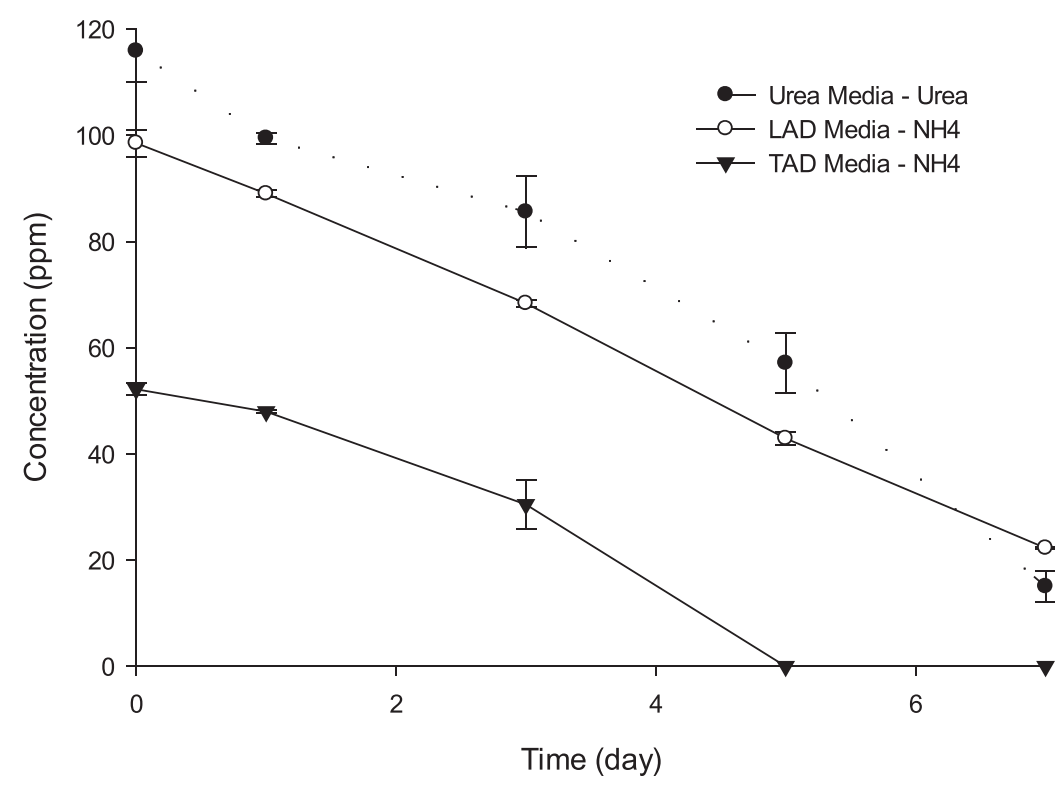

FIG. 9. Urea and ammonium (NH4) consumption in the media with the addition of liquid digestate (LAD) and total digestate (TAD). Error bars represent standard errors $(n=3)$. 


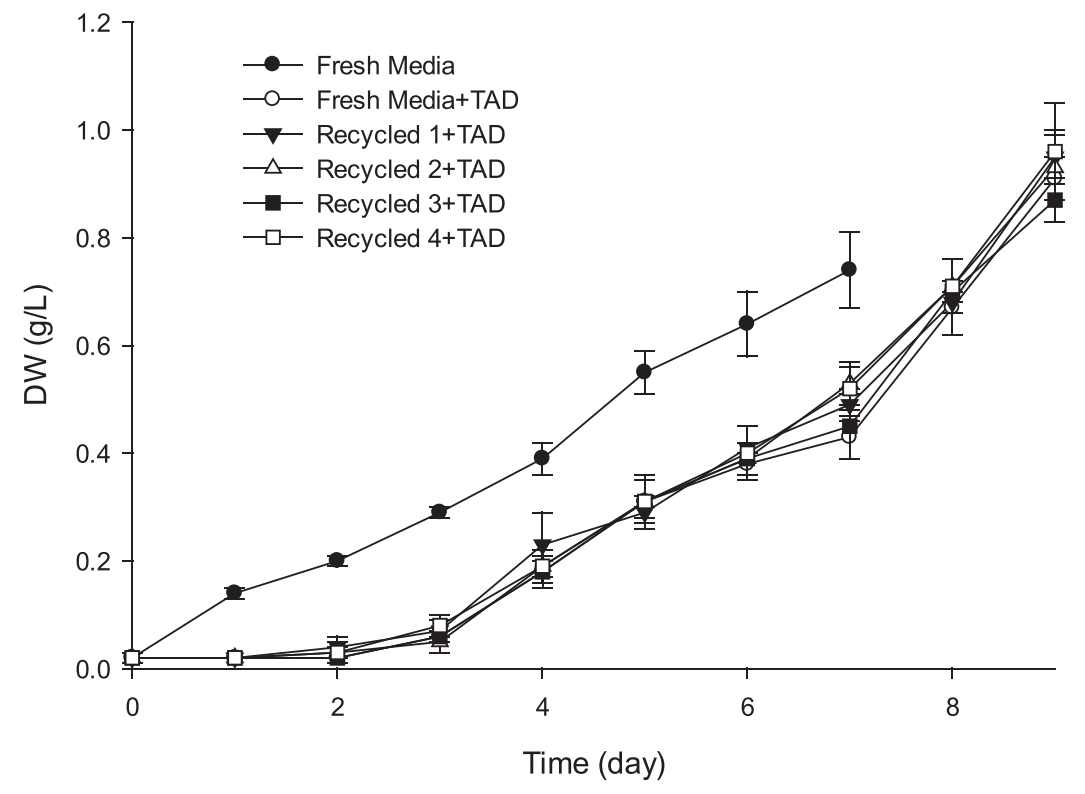

FIG. 10. Algae growth in fresh and recycled media with the addition of total digestate (TAD). Error bars represent standard errors $(\mathrm{n}=3)$

four days. The ammonium concentration in these flasks fluctuated around $25 \mathrm{ppm}$ during the exponential growth phase. In the flasks containing recycled media plus TAD, ammonium was exhausted on the fourth or fifth day, after which nitrogen should have become a growth limiting factor. However, from Figure 10, it was evident that the nitrogen depletion did not result in any slowing of algae growth up to the end of the experiment. It appears that for a short period of time, algal cells are able to self-sustain on the intracellular nitrogen pool.

Finally, it is worth noting that urea uptake was affected by the presence of ammonium. The competitive uptake of urea and ammonium is likely governed by the Scenedesmus urea uptake pathway and cell feedback regulation. Prior to joining the nitrogen assimilation pathway,

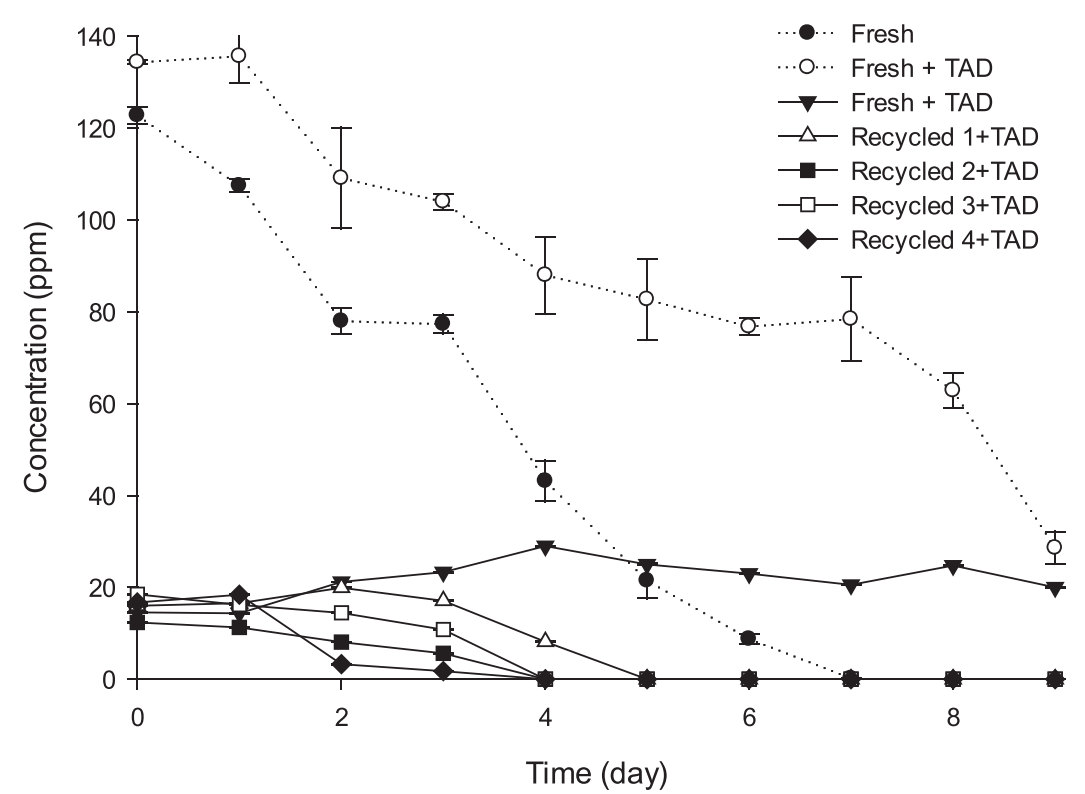

FIG. 11. Ammonium (solid lines) and urea (dotted lines) consumption in fresh and recycled media with the addition of total digestate (TAD). 
urea is passively transported into the Scenedesmus cell and reduced to $\mathrm{NH}_{4}{ }^{+}$by ATP: urea amidolyase (Thompson and Muenster, 1971). The accumulation of intracellular $\mathrm{NH}_{4}{ }^{+}$can result in the feedback inhibition of extracellular $\mathrm{NH}_{4}{ }^{+}$and urea uptake by repressing expression of the corresponding enzymes (Mulholland and Lomas, 2008).

It is also worth noting that the inhibition may not be caused by the $\mathrm{NH}_{4}{ }^{+}$alone, rather by the intermediate products from the downstream nitrogen assimilation pathway. Evidently, when ammonium assimilation reached equilibrium, the hydrolysis of urea decreased and a stabilized ammonium extracellular pool was observed in the Fresh media + TAD flasks.

To eliminate the lag phase observed when using TAD as a nutrient, while replacing the maximum amount of urea possible with ammonium from the digestate, LAD was examined as a nutrient supplement for recycled media. As shown in Figure 12, use of LAD resulted in the virtual elimination of the lag phase. However, compared to recycled media with total digestate (Figure 10), the specific growth rate decreased from $0.1 \mathrm{~g} / \mathrm{l} / \mathrm{day}$ to $0.085 \mathrm{~g} / \mathrm{l} / \mathrm{day}$. Moreover, the algae growth rate in recycled media to which LAD was added was slower than the control within the 7-day exponential phase $(\mathrm{F}=29.74, \mathrm{p}<0.0001)$, the final biomass accumulation for the control and recycle experiments being, respectively, $0.90 \mathrm{~g} / \mathrm{l}$ and $0.60 \mathrm{~g} / \mathrm{l}$.

Media recycled between one and four times did not produce any significant differences in algae growth rates $(\mathrm{F}=1.49, \mathrm{p}=0.2901)$. Fresh media with LAD rendered higher specific growth rate than the fresh media alone $(0.122$ vs. $0.104 \mathrm{~g} / \mathrm{l} / \mathrm{d}, \mathrm{F}=8.38, \mathrm{p}=0.044)$. Again, the inhibition of urea uptake was observed. In the flasks where urea formula was added along with $\mathrm{LAD}$, only $16 \%$ of the urea was consumed (Figure 13). Ammonium was exhausted in most of the flasks by the last day of the experiments, except for the experiment labeled Recycled $4+\mathrm{LAD}$, which had $15 \mathrm{ppm}$ of ammonium remaining. Ammonium imposed an inhibition on urea assimilation; however, urea did not appear to have a similar effect on ammonium uptake. Evidently, nitrogen was not the limiting factor on growth since ammonium was present in all of the experiments up to day 6 or 7 .

The possible limiting factors for the slower growth with recycled media could be the slight increase in the turbidity of the media or growth inhibitors. Recycled media was isolated from the algae growth stock by centrifugation, and contain a certain amount of dead algae cells and debris, resulting in cloudiness. The existence of growth inhibitors excreted by algae cells can also limit the growth of new generation algae cells (Richmond, 2004 and Sun et al., 2008). Sun et al. (2008) extracted a type of growth-inhibitor from the old cultivation medium

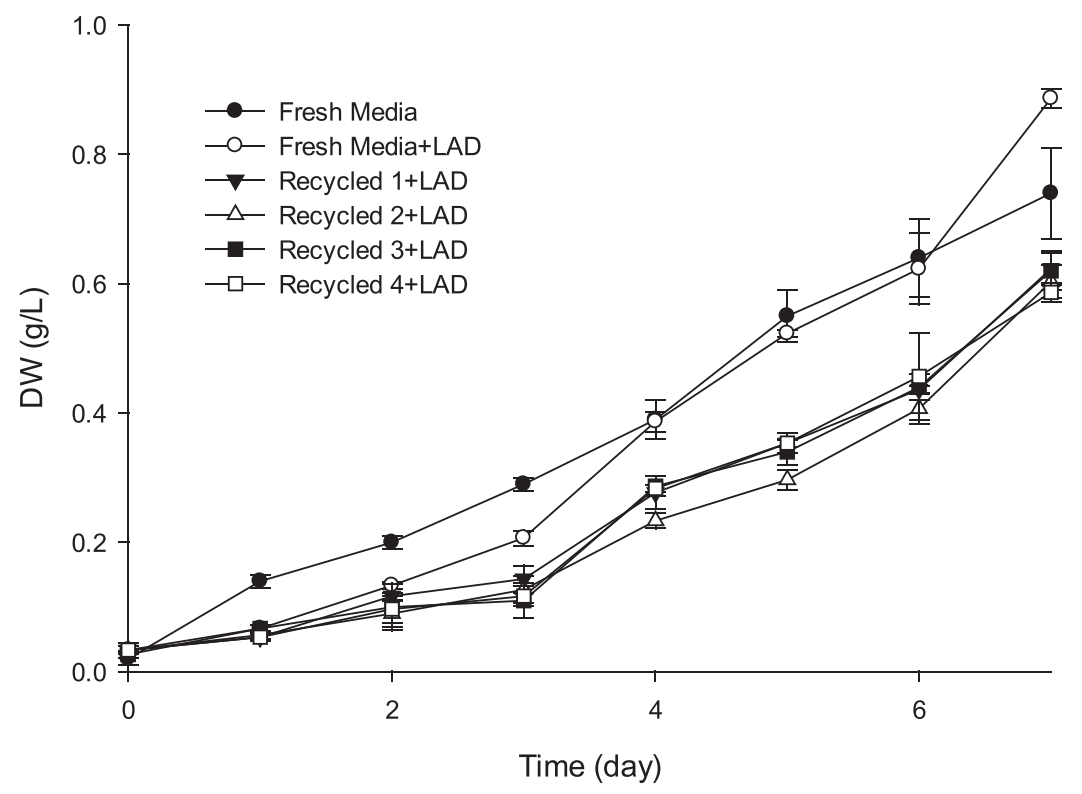

FIG. 12. Algae growth in fresh urea media (with and without liquid digestate) and recycled media with the addition of liquid digestate (LAD). Error bars represent standard errors $(n=3)$. 


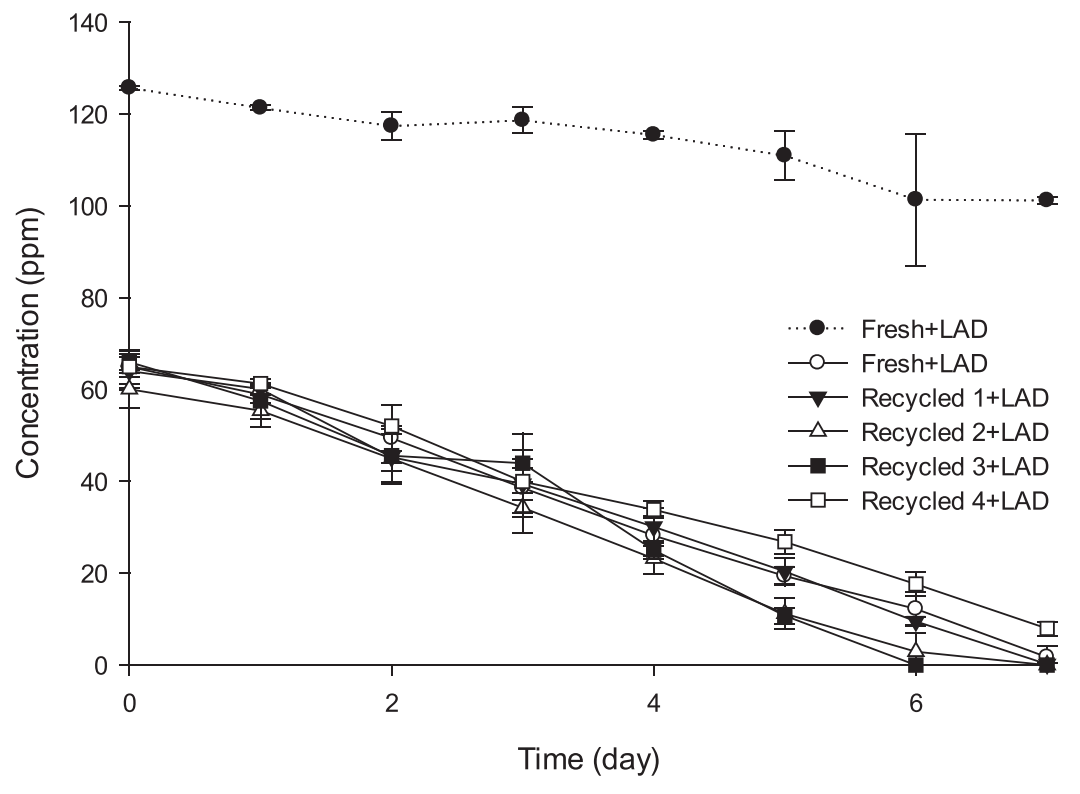

FIG. 13. Consumption of ammonium (solid symbols) and urea (open symbols) in fresh urea media and recycled media; in all cases, liquid digestate (LAD) was added.

of Isochrysis galbana, and determined its molecular structure as 1-[hydroxyl-diethyl malonate]-isopropyl dodecenoic acid $\left(\mathrm{C}_{22} \mathrm{H}_{38} \mathrm{O}_{7}\right)$. The growth-inhibitor not only inhibited the growth of Isochrysis galbana but also limited the synthesis of chlorophyll and protein. Sun et al. (2008) also applied this growth-inhibitor to Chlorella vulgaris, and the growth of Chlorella vulgaris was significantly inhibited compared to the control.

\section{CONCLUSIONS}

This study provides evidence that recycled media from algal biomass harvesting and dewatering can be recycled for biomass cultivation at least four times without any deleterious effect. A second finding is that anaerobic digestate derived from algal biomass is a promising nutrient source for algae cultivation. Addition of total digestate (solid plus liquid) to algae cultures can cause high turbidity; therefore, placing limits on its application if high light penetration is to be maintained. However, the addition of liquid digestate results in much lower turbidity and therefore less dilution is required. Ammonium from anaerobic digestate proved to be an efficient nitrogen source for algae growth, although its presence inhibited urea assimilation to a certain degree. For potential practical applications, prior to addition, the determination of anaerobic digestate composition is recommended, in order to provide appropriate amount of nutrients to the algal culture.

\section{ACKNOWLEDGMENTS}

The information reported in this paper (16-05-017) is part of a project of the Kentucky Agricultural Experiment Station and is published with the approval of the Director. The authors would like to thank the Kentucky Department of Energy Development and Independence for funding and Dr. Jennifer Aurandt for supplying the anaerobic digestate.

\footnotetext{
Alburquerque, J. A., de la Fuente, C., Ferrer-Costa, A., Carrasco, L., Cegarra, J., Abad, M., and Bernal, M. P., “Assessment of the fertilizer potential of digestates from farm and agroindustrial residues," Biomass Bioenergy 40, 181-189 (2012).

Arthurson, V., "Closing the global energy and nutrient cycles through application of biogas residue to agricultural landPotential benefits and drawbacks," Energies 2, 226-242 (2009).

Crofcheck, C., E, X., Shea, A., Montross, M., Crocker, M., and Andrews, R., "Influence of media composition on the growth rate of Chlorella vulgaris and Scenedesmus acutus utilized for $\mathrm{CO}_{2}$ mitigation," J. Biochem. Technol. 4, 589-594 (2012).
} 
E, X. and Crofcheck, C., "Pretreatment of Scenedesmus biomass as a potential anaerobic substrate," Biol. Eng. Trans. 7(1), 41-52 (2014).

Franchino, M., Comino, E., Bona, F., and Riggio, V. A., "Growth of three microalgae strains and nutrient removal from an agro-zootechnical digestate," Chemosphere 92, 738-744 (2013).

Glass, J. B., Wolfe-Simon, F., and Anbar A. D., "Coevolution of metal availability and nitrogen assimilation in cyanobacteria and algae," Geobiol. 7, 100-123 (2009).

Healey, F. P., "Inorganic nutrient uptake and deficiency in algae," Crit. Rev. Microbiol. 3, 69-113 (1973).

Iyovo, G., Du, G., and Chen, J., "Sustainable bioenergy bioprocessing: Biomethane production, digestate as biofertilizer and as supplemental feed in algae cultivation to promote algae biofuel commercialization," J. Microb. Biochem. Technol. 2, 100-106 (2010).

McGlathery, K. J. and Pedersen, M. F., "The effect of growth irradiance on the coupling of carbon and nitrogen metabolism in Chaetomorpha linum (Chlorophyta)," J. Phycol. 35, 721-731 (1999).

Moller, K. and Muller, T., "Effects of anaerobic digestion on digestate nutrient availability and crop growth: A review," Eng. Life Sci. 12, 242-257 (2012).

Mulholland, M. R. and Lomas, M. W., "Nitrogen uptake and assimilation," in Nitrogen in the Marine Environment, 2nd ed., edited by Capone, D. G., Bronk, A. D., Mulholland, M., and Carpenter, E. J. (Elsevier, Amsterdam, 2008), pp. 293-374.

"Biological principles of mass cultivation," in Handbook of Microalgal Culture: Biotechnology and Applied Phycology, edited by Richmond, A. (Blackwell, Science, Oxford, 2004), pp. 125-177.

Shin, H.-Y., Ryu, J.-H., Bae, S.-Y., Crofcheck, C., and Crocker, M., "Lipid extraction from Scenedesmus sp. microalgae for biodiesel production using hot compressed hexane," Fuel 130, 66-69 (2014).

Sun Y., Wang C., and Chen J., "Growth inhibition of the eight species of microalgae by growth inhibitor from the culture of Isochrysis galbana and its isolation and identification,” J. Appl. Phycol. 20, 315-321 (2008).

Syrett, P. J., "Uptake and utilization of nitrogen compounds," in Biochemistry of the Algae and Cyanobacteria, edited by Rogers, L. J. and Gallon, J. R. (Clarendon Press, Oxford, 1988).

Thompson, J. F. and Muenster, A. E., "Separation of the Chlorella ATP: Urea amidolyase into two components," Biochem. Biophs. Res. Commun. 43, 1049-1055 (1971).

Wilson, M. H., Groppo, J., Placido, A., Graham, S., Morton, S. A., Santillan-Jimenez, E., Shea, A., Crocker, M., Crofcheck, C., and Andrews, R., "CO $\mathrm{CO}_{2}$ recycling using microalgae for the production of fuels," Appl. Petrochem. Res. 4, 41 (2014).

Young, E. B. and Beardall, J., "Photosynthetic function in Dunaliella tertiolecta (Chlorophyta) during a nitrogen starvation and recovery cycle," J. Phycol. 39, 897-905 (2003). 